\title{
INFORMATION PROVIDED BY SPANISH UNIVERSITY WEBSITES ON THEIR ASSESSMENT AND QUALITY PROCESSES
}

\author{
María Pinto $^{1}$, David Guerrero ${ }^{2}$, Andrés Fernández-Ramos ${ }^{1}$ and Anne-Vinciane Doucet ${ }^{1}$ \\ (1) Department of Information Science, University of Granada, $\mathrm{P}^{\circ}$ de Cartuja, s/n, 18071 Granada, Spain \\ (2) Human Resources Office, University of Granada, Granada, Spain
}

Address for correspondence: Andrés Fernández-Ramos, Department of Information Science, University of Granada, $\mathrm{P}^{\circ}$ de Cartuja, s/n, 18071 Granada, Spain. E-mail: afernandezster@gmail.com

\begin{abstract}
We analyze and evaluate the information provided by Spanish public universities on the web about their assessment and quality processes with the aim of detecting aspects for improvement and identifying best practices in universities that could act as a benchmark for the rest of the sector. A tested model/template incorporating a set of criteria and indicators is used to determine the quality of this information. The strengths and weaknesses of institutional websites are analyzed at both individual level and as a whole; the possible relation between website quality and the characteristics of the universities is also examined.
\end{abstract}

\section{Introduction}

Today, we are witnessing a new stage in the history of humanity, the Information and Knowledge Society, about which numerous reflections have been made, and will continue to be made, on the factors that have triggered it, its implications and its consequences. Many theoretical and empirical papers have been written on the subject from scientific, sociological and cultural perspectives (European Commission, 2006; Michel, 2004). Information as a unique consumer good is reaching spectacular proportions in this new age. On one hand, we are witnessing the enormous production of information by a growing volume of media, avidly consumed by the public and thus driving the information industry forward at even greater speed. On the other hand, the binary nature of the way information is presented today lends it certain characteristics that are revolutionising the traditional and conventional forms of presentation and transmission that have been present since the invention of the printing press. A notable characteristic of digital information is the way it can be processed by computerised media, thus favouring new types of access and handling. Interactive and participative information systems and models are proposed in an attempt to attract the individual's attention. Of course all of this is possible thanks to the opportunities offered by digital information (Dillon \& Song, 1997; Bodomo, 2006; Frumkin, 2006; Walther, Gay \& Hancock, 2005): interactivity, navigability, hypertextuality, ease of reuse, ubiquity (enabling various users to access and work on the same document at the same time but from different locations), recoverability (ability to use different search mechanisms, simple or complex, to recover information). All these properties give on-line information products a unique value in the current communication scenario, both for information creators and distributors, and for those who receive and use it. Internet, and in particular the world wide web, embody this indispensable technology for the information society, as they enable rapid, accurate and above all global access and exchange of information, thereby universalising the concept of diffusion of and access to information. Other technologies all appear to revolve around this axis, the Internet. 
However, the true societal revolution, with information at the forefront, does not only lie in large quantities and accumulation of data, but in the rational and intelligent use that is made of this information to transform it into productive development and positive evolution. In other words, information takes on a productive meaning when it is secured, assimilated and transmitted as knowledge by universities, academic institutions, social or community groups and organisations, and is reused intelligently and thoughtfully (UNESCO, 2005).

As a strategic measure, universities should cultivate and strengthen their informative role, both from an endogenous perspective for decision making, and from an exogenous perspective, in generating real data on their results and the impact they have in society. Moreover, they must rise to an important challenge: the harmonisation of the culture of innovation and lifelong learning with a long-term strategic view of the organisation underpinning its mission and objectives, within the framework laid down by what is known as the "Bologna Process" (Reichert \& Tauch, 2005; EUA, 2003). In this vein, one of the main targets proposed in the directives of the new European Higher Education Area (European Commission, 2001a; 2001b) is the promotion of European cooperation to safeguard quality, with a view to developing comparable criteria and methodologies among European university institutions. Spanish publicly funded universities have built on previous experience to set up specific mechanisms using institutional processes to assess the quality of teaching, research and services, in order to find out their strong and weak points and put forward plans for improvement.

The analysis of the diffusion and impact of the digital information that university academic websites provide about the processes of higher education assessment and accreditation, the objective of the present study within the scope of Spanish universities, can be extremely useful for a variety of reasons: a) to obtain a picture of the distribution and diffusion of the digital information on this subject that the organisation transmits and projects beyond its boundaries, b) to provide a diagnosis of the achievements and challenges met by Spanish universities in terms of the quality, integration and reuse of the information offered on their websites, and c) as an individual and social endeavour to standardise and publicise the information resulting from these assessment processes (reports, etc....), for the academic community and society as a whole, for the sake of greater transparency.

\section{Quality Assessment and Accreditation Processes in Spanish Universities}

Higher Education has been the subject for study, meetings and debate in both national and international forums during recent years, as evidenced by the UNESCO World Declaration on Higher Education in the $21^{\text {st }}$ Century (1998), documents published by the European Network for Quality Assurance in Higher Education (ENQA), and the Commission of the European Communities: The Role of Universities in the Europe of Knowledge (2003). All these documents establish the key elements of the new emerging paradigm of Higher Education, grounded on a series of basic concepts such as innovation, lifelong learning, diversification, competitivity, quality assessment, financial, academic and social accountability and transparency, multiliteracy, information literacy, new technologies, international cooperation, mobility and so on. These concepts reinforce the important role of Universities in the Europe of Knowledge, (Commission of the European Communities, 2003) both in teaching and in research and exploitation of scientific results, in attaining socioeconomic and strategic advantages in a competitive society, favouring the creation of more and better quality jobs and greater social cohesion. However, quite a number of 
Spanish universities must overcome certain structural limitations related to the information they generate and publish on their web sites, such as:

- scant strategic vision of the role of quality information in the new globalised arena, where the management, sharing and diffusion of electronic information constitutes the main asset for their development.

- scant relevance and impact of the information on academic websites about the achievements and results obtained from institutional assessment and quality processes, which leads to disinterest and apathy among members of the university community.

- absence of a common university policy providing guidelines for the standardisation of communication and circulation of academic digital information on university websites, thus hindering information accessibility and dissemination.

In the European framework, practically all countries have consolidated systems in place to assess their Higher Education institutions. The culture of quality assessment began to take shape in the eighties, beginning in the Netherlands, France and the United Kingdom, and then spreading to practically all other European countries (Haug \& Kirstein, 1999; Haug \& Tauch, 2001; Michavila, García \& Rodríguez, 2001; Michavila \& Martínez, 2002). In the eighties, various Western university systems (Consejo de Universidades, 2000), including Spain, introduced new legal frameworks based on the concept of university autonomy. The basic argument for this transformation was that autonomy was considered as a decisive instrument with which to achieve the objectives of higher education quality and progress in these countries. It is assumed that because it is grounded in the principle of self-regulation, university autonomy favours innovation, improves efficiency, raises effectiveness and leads to greater levels of responsibility.

In the latter years of the $20^{\text {th }}$ century in Spain, universities therefore introduced a series of assessment and quality plans and programmes, as a result of the social, cultural, economic and technological changes occurring in the developed Western world. In addition, the redefinition of higher education, the securing of resources and clients and the introduction of a new model centred on the student, lifelong learning and the new roles of tutors and academics as facilitators of this learning have helped to bring about greater social awareness of the demand for quality in university products, results and services and of the need to use human, material and economic resources efficiently in accordance with the priorities and objectives defined by the universities. Knowing, valuing and measuring the progress and performance of the services universities offer in their environment have become priorities for all types of strategic management.

The term accountability has become popular to describe university practices referring to information provided on the good use of public resources and efficient functioning of the higher education system. Universities should serve society; society should be informed and perceive that its needs are attended to and adequately responded to by its universities (Hernon, Dugan \& Schwarts, 2006; Mora, 1991; Michavila, 2001).

Institutional assessment of universities is a process of support for continuous improvement as a guarantee of the institution's quality, to safeguard its mission, targets and objectives, thereby achieving the satisfaction of its clients. It emerges as a way of verifying that the institution is meeting its objectives, by simultaneously analysing the means and the results. It is a relative, multidimensional process characterised by its great flexibility and adaptability to the context and to the institution it is evaluating, and combines both internal and external perspectives of quality through comprehensive assessment procedures covering the entire institution: teaching, learning outcomes, research, services and management (AQSUC, 2000). Therefore, assessment consists of 
systematically obtaining evidence of objective information, both qualitative and quantitative, that facilitates decision making (Seminario Internacional sobre Evaluación de la Calidad y la Acreditación en la Enseñanza Superior Unión Europea, América Latina y el Caribe (2003) International Seminar on Quality Assessment and Accreditation in Higher Education in the European Union, Latin America and the Caribbean).

To this end, the metainformation on the information dealing with assessment and quality becomes vital in enabling the organisation to gather, in a structured way, a wide variety of dispersed information (data, evidence, indicators, opinions etc.), and provides it with the coherence and consistency to fulfil the mission, targets and objectives it has set itself.

\section{Analysis and assessment of Internet information.}

Internet information is characterised by the instability of its contents, decentralisation of locations, multiplicity of forms, diversity of user groups, and dynamics of the environment (Zhang \& Dimitroff, 2005). But the quality of this vast amount of information now available on the Internet is not always as high as it perhaps should be, due to the fact that there are no guidelines (or at least they are not always followed) to ensure the quality of a web resource.

McMurdo (1998) advocated evaluating the quality of Internet-related documents because publishing was open to anyone with a computer and a connection to the Internet. The ease of publishing has re-emphasised the need to critically evaluate the quality of published information.

For this reason, we must define the characteristics we want this type of information resource to have and the assessment criteria that we can use to determine its value and usefulness. This issue has attracted a good deal of interest in recent years due to the growing importance of Internet resources as a means of disseminating information, particularly scientific information, and the need to evaluate and filter this information has become evident. The need to evaluate the electronic resources available on the Internet is confirmed by the way this evaluation has become a priority generic skill within what is known as information literacy, and is one of the main standards in this respect (ACRL, 2000; AASL \& AECT, 1998; SCONUL, 1999; ANZIIL \& CAUL, 2004).

As a result, numerous studies have appeared in the scientific literature on the criteria to be applied in evaluating web-based resources:

In a study of the literature published up to that time, Smith (1997) drew up a set of criteria for evaluating the quality of web-based resources and divided them into 7 categories: scope, content, graphic \& multimedia design, purpose $\&$ audience, reviews, and workability and cost.

Both Alexander and Tate (1999) and Beck (1997) or Kapoun (1998) propose five fundamental criteria (accuracy, authority, objectivity, currency and coverage), together with the associated indicators that can be used to measure them.

Miller (1996) deals with the different dimensions from which the relevance and accuracy of web resources can be perceived: its currency (timeliness), the degree of completeness and format, how well the information "hangs together" (coherence), how accessible it is, how it can be combined with other information (compatibility), how secure it is and whether it can be verified as being true (validity). McInerney \& Bird (2004) identify nine criteria: content, functionality, authority, currency, links, graphics, coverage, style, and use of meta-tags. Dragulanescu (2002) suggests the following 
eight: accuracy, authority, coverage, currentness, density, interactivity, objectivity and promptness. Pitschmann (2001) classifies web-based resource evaluation criteria into four categories:

- Context Criteria: Provenance; Relationship to other resources.

- Content Criteria: Validity, accuracy, authority, uniqueness, coverage, currency, audience.

- Form/Use Feature (Accessibility) Criteria: Composition and site organisation, navigational features, recognised standards and appropriate technologies, user support, terms and conditions, rights legitimacy.

- Process or Technical Criteria: Information integrity, site integrity, system integrity.

In addition, a number of indicators and models for evaluating websites associated to a particular domain have also been developed, as is the case for libraries (Chao, 2002; Clausen, 1999; Olsina, Godoy, Lafuente \& Rossi, 1999), business organisations (Barnes \& Vidgen, 2001; 2002; Miranda \& Bañegil, 2004) or medical information (Bernstam, Shelton, Walji \& Meric-Bernstam, 2005; Jadad \& Gagliardi, 1998; Kim, Eng, Deering \& Maxfield, 1999; Haddow, 2003).

\section{Methodology}

This study adapts the methodology used in "Metric Analysis of the information visibility and diffusion about the European Higher Education Area on Spanish University Websites" (Pinto, Sales, Doucet, Fernández-Ramos \& Guerrero, 2007) to the aim of the present study: the information provided by Spanish public universities on the web about their assessment and quality. A data gathering tool was specifically designed for the purposes of the abovementioned study. To this end, criteria were gathered from an analysis of the scientific literature, and their usefulness for that study was analysed; brainstorming sessions were held to select the most suitable criteria; a template was designed in which the criteria were specified by particular indicators; the indicators were weighted and finally the websites were analysed with reference to the specially designed template. Data were subsequently then tabulated and analysed from descriptive and comparative perspectives; a SWOT analysis (Strengths, Weaknesses, Opportunities and Threats) was also carried out.

Since the usefulness of the template designed for the abovementioned study to evaluate university websites had already been demonstrated, we had to modify it for the present study para adaptarla a la temática que abordamos ahora. The essential structure of the template was retained, based on seven main criteria: visibility, authority, updatedness, accessibility, correctness and completeness, quality assessment and navigability, although indicators for the "accessibility" and "correctness and completeness" criteria were modified as follows:

- In the case of "accessibility" 6 indicators were used instead of 8 since the two that referred to information in other languages were only applicable to certain universities and may have distorted the results.

- Several different indicators were used in the "correctness and completeness" criteria because the information on websites about the European Higher Education Area differs from that on websites dealing with assessment and quality processes. 
The selection of new indicators for the "correctness and completeness" criterion and the rest of the data gathering and data analysis procedures followed the same methodology used in the previous study.

Results were subsequently compared with those obtained in a study into the diffusion and visibility of information on the EHEA offered by Spanish universities (Pinto, Sales, Doucet, Fernández-Ramos \& Guerrero, 2007) in order to reveal differences between the two websites.

\section{Evaluation criteria}

The seven criteria were divided into a total of 70 indicators, although not all the criteria have the same number of indicatorssince the number of indicators that could be used varied from one criterion to another and also because we considered some aspects to be more important than others; we judged the most important to be "correctness and completeness" and "visibility". In contrast to the EHEA study, the indicators in this study were not weighted and they therefore all have the same value. This was done to eliminate subjectivity in the evaluation process since although the importance of a certain criterion can be determined by the number of aspects it has to be evaluated (indicators), assigning one indicator with twice the value of another may be considered much more subjective.

a) VISIBILITY OF INFORMATION (17 indicators). The purpose of this criterion was to analyse the extent to which the information examined can be easily and intuitively located from the university's website home page.

The indicators selected to study this criterion referred to: the existence of a direct link from the home page; a reference in the university's table of contents; whether the information is clearly organised; existence of a search engine (and if so, whether advanced search options are available that enable restriction to quality assessment); and whether metadata were used in the construction of these resources to facilitate their location and identification.

b) AUTHORITY (2 indicators). The credibility of information offered in any format essentially lies in knowing the identity of the author of the information. It is therefore essential that the authorship of the resource is perfectly and clearly indicated and readily visible.

The indicators used to evaluate this aspect were: the presence of the university name, logo and webmaster data.

c) UPDATEDNESS (3 indicators). Processes of university quality assessment, as we understand it today, are a relatively recent phenomena in the world of higher education. New standards, recommendations and practises are constantly being established. The people involved in these processes must be able to access this information from the moment its implementation has been agreed upon. It is therefore crucial that the areas on university websites given over to this information be updated as frequently as possible.

This criterion was measured by noting whether the date of the latest update was included, whether obsolete links were present, and whether news, innovations and announcements sections were well maintained. 
d) ACCESSIBILITY (6 indicators). This criterion was included to measure the degree to which accessibility was considered in the construction of the website to ensure that it could be used by everyone, regardless of individual characteristics or possibilities. The indicators used were: whether the information could be seen with any browser, whether websites were adapted for people with disabilities (particularly through the use of the $\mathrm{WAI}^{(1)}$ standard), whether versions were available in different formats, and whether version were provided in English. Two indicators used in the EHEA article, referring to versions in the languages of the autonomous region, were eliminated because only some of the universities analysed belong to autonomous regions with their own language.

e) CORRECTNESS AND COMPLETENESS (35 indicators). This was considered to be the most important criterion, as it provides direct evidence of the content and the information provided by the resource.

The factors taken into account to evaluate the correctness and completeness of a webbased resource were: the scope of the resource, its coverage, the quality of the information it provides and whether it offers the best and most comprehensive information on the subject. Many of the indicators used in this criterion differed from those used to evaluate websites about the EHEA because the information they deal with is very different. For this study we determined which information on assessment and quality should appear in a university web-based resource, and established a set of indicators to find out whether this information was actually provided (links, general information, standards, agenda, programmes, calls and announcements, innovations and a directory of people and institutions).

f) QUALITY ASSESSMENT (3 indicators). This criterion enabled us to determine whether the university had a policy on web-based resource quality, and the importance given to it by those responsible for its management. The indicators selected were: the existence of a quality policy reflected on the website, the availability of a suggestions box, and whether user satisfaction surveys were carried out.

g) NAVIGABILITY (4 indicators). This criterion refers to the ease with which the resource is navigated, the clarity of its sections and complete awareness by the user of which part of the website he or she is consulting at all times. To this end, we studied the content menus, consistent use of terminology and the existence of navigation buttons.

Take in Table 1

\section{Data collection and analysis.}

The study population comprised all Spanish publicly funded universities, a total of 50 higher education institutions. The websites of these universities were taken from the list provided by the Spanish Ministry of Education and Science ${ }^{(2)}$, and was compared with the list on the website of the Conference of Spanish University Rectors $^{(3)}$. However, we were only able to analyse 47 of the 50 , since at the time of the study, the Universidad Internacional Menéndez Pelayo, the Universidad Pablo de Olavide and the Universidad Politécnica de Valencia had no website devoted to quality assessment in their institutions.

Data was gathered manually during the second fortnight of November 2006. The information was compiled by visiting each university's website, with a view to locating (where it existed), the page devoted specifically to assessment of quality at the 
university. Where no direct link to these pages was provided, we used the search engine, which was available on most of the universities' websites. The search terms chosen were "university quality assessment", "teaching assessment", "university quality" and "institutional assessment". In the case of universities in autonomous regions with two official languages, these terms were translated into the corresponding language.

All the results were verified, based on simultaneous evaluations by the study authors, to confirm the legitimacy of the evaluation. Few disagreements arose over the evaluations for various reasons: the indicators could only take a positive or a negative value; many of them could be evaluated very objectively (there is entry from the homepage, there is a version in English, the date of the last update appears...); the authors had worked together in designing the data gathering template and had reached a consensus on how to evaluate each indicator with the help of real examples; and they already had previous experience in evaluating university websites with a very similar template and therefore with fairly similar criteria. However, when opinion was divided, the final decision was reached through consensus; each evaluator exposed the reasons for his or her evaluation and the all the evaluators debated the arguments until at least three of the four evaluators were in agreement, in which case the majority opinion wasadopted.

A SWOT (Strengths, Weaknesses, Opportunities and Threats) analysis for each university formed part of the overall analysis of the data obtained. The information was processed as follows:

- The evaluation instrument used in the data gathering process was based on affirmative and negative responses to the indicators (a score of 1 was given if the response was positive, and 0 if it was negative). The total number of positive responses was calculated. This revealed the number of criteria each university fulfilled. We then calculated the percentage of positive responses.

- From these percentages, we assigned a numerical value of between 1 and 5 in order to obtain a rating as follows:

Take in Table 2

This score was calculated for each university both at an overall level, and for each of the seven criteria.

The official acronyms of the 50 Spanish publicly funded universities were used (see appendix I), and appear as such in the figures and tables below. These acronyms are the ones that appear on each university website; if the reader so wishes, he or she can easily locate the desired webpage by adding .es to the end of each acronym.

\section{Results.}

We analysed the results obtained for each of the main criteria so as to provide a clear, detailed view of the general actions taken by the universities on each of the aspects studied, together with the particular actions at each university. Similarly, an overall evaluation was made that includes each university's score on each criterion and its overall score. These data gave us an idea of each university's strong and weak points.

In the following box plots, corresponding to the websites on Assessment and Quality and to those on the European Higher Education Area (EHEA), the minimum value, the lower quartile, the median, the upper quartile and the maximum value of the percentages obtained are given for each of the seven main criteria. 
The results obtained from our visibility indicators are relatively modest, with the mean score barely reaching the "pass mark" (7.8 out of a total of 17 points). Most of the universities are rated as Acceptable $(39,82.98 \%)$, as they fall within the range of 6.8 and 10.2 points, although most of the values tended to be low. Of all the universities evaluated, only $2(4.26 \%)$ were rated Good, while $6(12.77 \%)$ were considered Poor. None of the universities were rated Not Acceptable.

Take in Table 3

Although slightly higher, these results are very similar to those obtained on the EHEA websites (Pinto et al, 2007), showing mean values of 4.82 and 4.54 on a scale of 0 to 10 . No significant differences were observed between the two when the t-test was applied with an error of $\alpha=0.05$.

If we analyse each of the indicators, we obtain a more detailed view of the actions taken by each university:

There was a direct link from the university's home page to the specific Quality Assessment page in 32 webpages $(68.09 \%)$; in contrast, access was not possible in only 5 cases $(10.64 \%)$.

We found that universities were careful to provide second level access: 34 universities $(72.34 \%)$ had a section on their home page with a sufficiently descriptive heading to direct potential users towards the specific section where they would find information on quality assessment.

Only four university websites (Cádiz, Oviedo, Las Palmas de Gran Canaria and León) have a map of the entire corporate website with links to contents. The rest (91.49\%) do not have this tool, which is particularly useful for navigating. Relatively well-structured tables of contents were found on the websites; however, these tables of contents were poorer on the specific Quality Assessment pages, and did not include any type of comment on the content. Two universities did not have this tool.

Nearly all the universities, $93.62 \%$ had a search engine, although only two of these $(4.26 \%)$ offered advanced search functions and allowed the search to be restricted to Quality Assessment. Of particular note is the fact that all the universities we analysed incorporate, to some extent or another, the use of metadata on their websites, thus making information easier to describe and identify.

As with the EHEA related websites, the greatest weaknesses revealed in Spanish universities with regard to the visibility of information on Quality Assessment are the lack of site maps, the functioning of search engines and the tables of contents specific to these pages.

\section{Authority}

In general, we found authorship to be one of the criteria that Spanish universities consider most important. The mean score was 1.27 out of a possible 2, and 14 universities (29.79\%) were rated Very Good.

The university logo and name appear in 46 cases (97.87\%), leaving no doubt as to which institution is responsible for the resource. 
However, only 14 universities $(29.79 \%)$ provide the contact details for the webmaster responsible for the Quality Assessment page. This is one of the areas that universities should work on to improve and correct the potential errors or problems detected by users.

The following table presents the results for each university:

Take in Table 4

The mean scores obtained (6.35) are slightly lower than those for the EHEA websites from the same universities (6.95), although no significant differences are appreciated between the two.

\section{Updatedness}

The two aspects evaluated in this criterion were:

Presence of the date the web page was last updated: positive values were found in 18 universities $(38.30 \%)$ for this indicator.

Existence of faulty/obsolete links: on the vast majority of the universities' websites no faulty links were found; however, only 18 (38.30\%) provide information on whether deadlines for calls or programmes had expired or not.

The following table presents the results obtained by each university:

Take in Table 5

The mean score obtained for this criteria was 1.62 out of a possible 3 (5.34 out of 10), which indicates that, while there is clearly room for improvement, the action universities take on the question of currency may be considered appropriate. This score is somewhat higher than that obtained for the EHEA websites (4.29 out of 10); however, due to the high standard deviations observed, we cannot conclude that any significant differences exist between the two with a value of $\alpha=0.05$.

\section{Accessibility}

If we presume that the final purpose of publishing a webpage is to provide access to information we believe our readers/users should be aware of, then the mediocre results obtained by most of the Spanish publicly funded universities on this issue is somewhat disheartening. The mean score was 3.77 out of a possible 7, barely reaching the "pass mark", with almost half the sample universities rated Poor (23 universities, $48.94 \%$ ).

Take in Table 6

An analysis of the five sub-criteria provides some interesting details: on their quality assessment web pages, only 8 universities use certain formats (such as Flash, Shockwave, etc.) that could hinder access, and all the universities offer pages that can be visited without problems, regardless of the browser used.

In contrast, only 3 universities $(6.38 \%)$ claim to apply WAI standards in the construction of their web pages, and only 5 (10.64\%) offer users any help on the structure and use of the web-based resource.

Printable versions of the information provided are offered by $97.87 \%$ of the universities.

An important aspect in relation to information accessibility is the language in which it is offered. Only four universities offer the same information in Spanish, in the second official language, and in English; a further 2, located in autonomous 
communities with only one official language, offer the same information in Spanish and English. The remaining universities (87.23\%) offer different information in the different languages, depending on the particular page visited.

When we compare the resulting mean score (5.47 out of 10$)$ with that obtained from the EHEA websites (4.04 out of 10), significant differences are observed between the two websites when the t-test is applied with a value of $\alpha=0.05$. These differences mainly derive from the scores in the sub-criterion referring to compatibility with different browsers/screen resolution; differences are minimum in the remaining subcriteria.

\section{Correctness and completeness}

This criterion was given most weight in the study, and consequently, we provide a more thorough analysis of our findings on this issue, as the aim of the study was to find out what information each university offers on the assessment of its quality. Therefore the bottom line is that, no matter how important the rest of the criteria might be, if the information provided is deficient, the resource cannot be considered valid.

As in the case of other criteria, Spanish publicly funded universities unfortunately do not reach the pass mark in this aspect, with a mean score of 16.74 out of 35. This criterion presents one of the highest Not Acceptable web ratings (17.02\%) in the study, which to a certain extent is offset by the $8.51 \%$ of websites that were rated as Very Good.

Take in Table 7

We used seven criteria, with their corresponding indicators, to evaluate dissemination of the information on assessment of qualityat the university:

1.- Searches in Spanish and English using the Google and Yahoo search engines revealed that the visibility of Spanish universities is very high in Latin American arenas (78.72\% of Spanish universities are ranked among the first hits returned by both search engines); in contrast, in the English speaking world, this rate is not so high, with an inferior $17.02 \%$.

2.- The "General Information" sub-criterion obtained an overall rating of Very Good, with a mean score of 4.43 out of 5 .

3.- In contrast, Spanish publicly funded universities do not generally reflect current European, national or regional standards on processes for assessing university quality. The overall score obtained for this criterion was 1.89 out of 5 . Bearing in mind the highly regulated nature of these processes, it is somewhat strange that universities do not provide their members (at least not publicly) with all the documentation that may be of interest to them.

4.- Only 19 universities (a scant 40\%) maintain an agenda of the congresses, workshops, meetings, etc., held on university quality assessment. This data is even more disappointing if we consider that only 9 of these universities keep this list up to date.

5.- The most important sub-criterion within the area of dissemination is without doubt that referring to the various programmes the university is involved in. We find only 19 universities reach the pass mark in this section (40.43\%), while the other 21 universities 
fail to obtain a third of the possible points. It comes as no surprise therefore, that the mean score for this sub-criterion lies at a very poor 6.02 out of 15 .

6.- Regarding participation in calls to events outside the university, the mean score is 2.34 out of 4 .

7.- We also considered it important to find out whether universities availed themselves of any method to attract users' attention to innovations arising on Internet about university quality assessment. Half the universities made use of such a system (26 universities, $55.32 \%$ )

The following table shows the scores obtained by each university on this criterion; both overall and sub-criterion scores are given.

Take in Table 8

This criterion revealed no significant differences from the scores obtained from the websites on the EHEA.

\section{Quality assessment}

We proposed 3 indicators for this criterion: publication of the quality policy adopted by the university; whether or not a suggestions box is provided; and whether any type of user satisfaction survey is carried out.

Our results are not particularly encouraging, with a mean score of 0.6 out of 3 .

24 universities scored no points on the three indicators; only the universities of Granada and Miguel Hernández define their quality policy and only 2 universities (Alicante and Cordoba) carried out surveys on the degree of user satisfaction with the web-based resources they offer; half of the universities did not even have a suggestion box.

These poor scores are practically the same as those obtained for the EHEA websites, in both cases close to a mean score of 1.95 out of 10 .

Take in Table 9

\section{Navigability}

Results were very encouraging for this criterion: $80.85 \%$ of the universities were rated Very Good or Good, while only 4 universities obtained poor scores, thus indicating the universities' concern to make navigation of their websites easy for users.

The average value obtained in this criterion (7.29 out of 10) is higher than that for the websites on the EHEA (6.44), although this difference was not significant when the two were compared using the t-test with a value of $\alpha=0.05$.

Take in Table 10

\section{Overall results}

From the above detailed analysis, the level of visibility and dissemination of the information made available by Spanish publicly funded universities on the processes of university quality assessment can be considered acceptable. Over half the universities studied obtained more than $50 \%$ of the total possible score, and the overall mean score 
was 52.05 out of 100 . No universities obtained a rating of Very Good (> 80\%), nor of Not Acceptable $(<20 \%)$, thus we can say that all the universities studied fell within the intermediate value range ( $>20 \%$ and $<80 \%)$.

The following table shows the overall score for each university in descending order and its scores in each of the seven criteria.

Take in Table 11

In order to determine whether the scores obtained by the universities were in any way related to their particular characteristics, we studied the correlations between the score and the following set of factors:

- Financial budget (taken from the universities' websites).

- Number of students at the university (data taken from the Instituto Nacional de Estadistica $^{(4)}$-National Statistics Institute- for academic year 2005-2006)

- Existence of an Assessment and Accreditation Agency in the autonomous community (data taken from the Agencia Nacional de Evaluación de la Calidad y Acreditación ${ }^{(5)}$ - National Quality Assessment and Accreditation Agency)

- Existence of a quality plan in the university (Data taken from the Universia portal).

Our results enable us to conclude that none of these four factors affects the scores obtained by the universities in any way, particularly with reference to the first three, which showed minimum correlations (below 0.1). The existence of a quality plan appears to have a certain influence (0.27), although it is not significant.

In order to verify whether any type of relation exists between the 7 main evaluation criteria, we performed Pearson correlation analyses. These revealed that no pair of variables had a correlation in excess of 0.5 , which confirms that the 7 criteria are independent of each other.

The highest correlation was found between "Correctness and Completeness" and "Visibility" (0.46), the two criteria with the largest number of indicators, and in our opinion, the most important.

These two criteria were exclusively used to show the results for each university on a two-dimensional graph. The following graph was plotted to show the position of the universities according to their coordinates in terms of Visibility and Correctness and Completeness. The $\mathrm{X}$ and $\mathrm{Y}$ axes take a value of " 0 " at the mean of each of these criteria and the coordinates are obtained by subtracting the value of each university from the mean. The graph shows that most of the universities are located in the lower left-hand and upper right-hand quarters, thus indicating to a certain extent (0.46 correlation) that the universities with a strength or weakness in one of these two criteria tend to respond fairly similarly in the other.

Take in Figure 2

\section{"Assessment and Quality" vs. "EHEA"}

A comparison of the overall scores of Spanish publicly funded university websites on Assessment and Quality and on the EHEA reveals them to be very similar; in both cases, the mean score is around 5 out of 10, and only in reference to accessibility do significantly better scores emerge for the Assessment and Quality websites as compared to the EHEA websites.

Take in Table 12 
It is however interesting to note that many universities with very good scores for their EHEA related websites did not achieve the same level on their Assessment and Quality websites; these include the universities of Valladolid (uva) and Barcelona (ub), the Politécnica de Cataluña (upc) and that of Valencia. And vice versa, the universities of Burgos (ubu), Salamanca (usal) and Vigo (uvigo) scored well in Assessment and Quality, yet obtained more modest scores in EHEA.

This somewhat curious situation leads us to consider that no clear policies exist in Spanish publicly funded universities on the information they make available on Internet, and the way in which they do so, and gives the impression that the content and form of the websites is decided by the respective university Vice-Rectorates.

\section{Conclusions.}

In our opinion, the results of this study are not as good as might have been expected, and universities must therefore turn their attention to providing their web pages with the contents that any Internet user interested in quality assessment in university institutions would expect to find there.

The main weaknesses found on Spanish university websites refer to aspects of quality assessment, correctness and completeness and navigability, while their main strengths are authorship and accessibility. The present study has highlighted and identified the best practices in each of the seven criteria analysed in order that they might serve as a reference to others as a benchmark for good practices.

The quality of the websites analysed could be significantly improved with relatively little effort, essentially in the form of greater interest on the part of those responsible for the websites. As we have seen, a good website does not depend on the size of the financial budget, nor on other factors related to the specific characteristics of each university; the fundamental issue lies in being aware of the importance for each organisation, and particularly for universities, of offering quality information and making this information public.

Scores for both the websites on Assessment and Quality and those on the EHEA have been shown to be deficient insofar as Quality assessment is concerned, which may well be one of the key points in explaining the overall set of results. We believe a positive step forward would be for Spanish publicly funded universities to devote greater efforts to improving the quality of their websites and for a series of guidelines or clear policies to be made available to them to that end. The template designed for this study could be used as a diagnostic tool to ascertain website quality, by helping to detect weak points and guiding those responsible for decision making on this issue.

\section{END NOTES}

(1) The W3C (1999) provide a check list to evaluate the degree of accessibility of a web-based resource that includes aspects such as frames, scripts, information presentation, navigation, etc.

(2) http://www.mec.es

(3) http://www.crue.org

(4) http://www.ine.es

(5) http://www.aneca.es 


\section{Appendix I.}

Take in Table 13

\section{REFERENCES}

ACRL - ASSOCIATION OF COLLEGE AND RESEARCH LIBRARIES (2000), Information

Literacy Competency Standards for Higher Education. ACRL, Chicago. Available: http://www.ala.org/ala/acrl/acrlstandards/standards.pdf

AASL \& AECT - AMERICAN ASSOCIATION OF SCHOOL LIBRARIANS \& ASSOCIATION FOR EDUCATIONAL COMMUNICATIONS AND TECHNOLOGY (1998), Information literacy standards for student learning: standards and indicators. Available: http://www.ala.org/aaslTemplate.cfm?Section=Information Power\&Template=/ContentManage $\underline{\text { ment/ContentDisplay.cfm\&ContentID }=19937}$

ALEXANDER, J. \& TATE, M.A. (1999), Web Wisdom: How to evaluate and create information quality on the web, Lawrence Erlbaum Associates, New Jersey.

AQSUC (2000), Formación de los Comités de Evaluación Externa. Agència per a la Qualitat del Sistema Universitari a Catalunya, Barcelona.

ANZIIL \& CAUL - AUSTRALIAN AND NEW ZEALAND INSTITUTE FOR INFORMATION LITERACY \& COUNCIL OF AUSTRALIAN UNIVERSITY LIBRARIANS (2004), Australian and New Zealand Information Literacy Framework: Principles, Standards and Practice, $2^{\text {nd }}$ ed. Editor: Alan Bundy. Available: http://www.caul.edu.au/infoliteracy/InfoLiteracyFramework.pdf

BARNES, S.J. \&. VIDGEN, R.T (2001), An Evaluation of Cyber-Bookshops: The WebQual Method, International Journal of Electronic Commerce, 6 : 6.25.

BARNES, S.J. \& VIDGEN, R.T. (2002), An integrative approach to the assessment of ecommerce quality, Journal of Electronic Research, 3 (3) : 114.127.

BECK, S. (1997), Evaluation Criteria. The Good, The Bad \& The Ugly: or, Why It's a Good Idea to Evaluate Web Sources. Available: http://lib.nmsu.edu/instruction/evalcrit.html

BERNSTAM, E. V., SHELTON, D. M., WALJI, M. \& MERIC-BERNSTAM, F. (2005), Instruments to assess the quality of health information on the World Wide Web: what can our patients actually use?, International Journal of Medical Informatics, 74 : 13.19.

BODOMO, A. (2006), Interactivity in web-based learning, International Journal of Web-Based Learning and Teaching Technologies, 1 (2) : 18.30.

CHAO, H. (2002), Assessing the quality of academia libraries on the Web: the development and testing of criteria, Library \& Information Science Research, 24 : 169.194.

CLAUSEN, H. (1999), Evaluation of library web sites: the Danish case, The Electronic Library, $17(2): 83.87$. 
COMMISSION OF THE EUROPEAN COMMUNITIES. (2003), The role of the universities in the Europe of Knowledge. Available: http://eurlex.europa.eu/LexUriServ/LexUriServ.do?uri=COM:2003:0058:FIN:EN:PDF

CONSEJO DE UNIVERSIDADES (2000), La evaluación institucional: concepto y método. Consejo de Universidades, Secretaría General.

DILLON, A. \& SONG, M. (1997), An empirical comparison of the usability for novice and expert searchers of a textual and a graphic interface to an art-resource database, Journal of digital information, 1 (1). Available: http://journals.tdl.org/jodi/article/view/jodi-1/2

DRAGULANESCU, N-G. (2002), Website quality evaluations: criteria and tools, International Information \& Library Review, 34(2) : 247.254.

EUROPEAN COMMISSION. (2006), Study on the economic and technical evolution of the scientific publication markets in Europe. Final Report. January 2006. Available: http://ec.europa.eu/research/science-society/pdf/scientific-publication-study en.pdf

EUROPEAN COMMISSION (2001a), Making a European area of lifelong learning a reality. Available: http://ec.europa.eu/education/policies/ll1/life/communication/com en.pdf

EUROPEAN COMMISSION (2001b), The eLearning Action Plan: designing tomorrow's education. Available: http://www.ntua.gr/dep/old/International/Europe/com2001_0172en01.pdf

EUA - EUROPEAN UNIVERSITY ASSOCIATION (2003), Graz Declaration: forward from Berlin: the role of the universities. Available: http://www.bologna-bergen2005.no/Docs/02EUA/0309Graz_publication.pdf

FRUMKIN, J. (2006), The need for a digital library service registry. OCLC Systems and Services, 22 (1) : 23.25.

HADDOW, G. (2003), Focusing on health information: how to assess information quality on the internet, Australian Library Journal, $52 \quad$ (2). Available: http://alia.org.au/publishing/alj/52.2/full.text/haddow.html

HAUG, G. \& KIRSTEIN, J. (1999), Trends I. In EUA. 2005. Trends and learning structures in higher education. Report Available: http://www.aic.lv/ace/ace_disk/acebook/Trends_all.pdf

HAUG, G. \& TAUCH, C. (2001). Trends II. In EUA. 2005. Trends and learning structures in higher education. Report series. Available: http://www.aic.lv/ace/ace disk/acebook/Trends all.pdf

HERNON, P., DUGAN, R.E. \& SCHWARTZ, C. (2006), Revisiting outomes assessment in higher education, Greenwood digital collection. Available: http://www.greenwood.com/catalog/LU2768.aspx

JADAD, A.R. \& GAGLIARDI, A. (1998), Rating health information on the Internet: navigating to knowledge or to Babel?, Journal of the American Medical Association, 279 (8) : 611.614.

KAPOUN, J. (1998), Teaching undergrads Web evaluation: A guide for library instruction. $C \& R L \quad N e w s, \quad 59 \quad$ (1). Available: http://www.ala.org/ala/acrl/acrlpubs/crlnews/backissues1998/julyaugust6/teachingundergrads.ht $\underline{\mathrm{m}}$. 
KIM P., ENG T.R., DEERING M.J. \& MAXFIELD, A. (1999), Published criteria for evaluating health related web sites: review, British Medical Journal, 318 (7184), : 647.649.

MCINERNEY, C. \& BIRD, N. (2004), Assessing Website quality in context: retrieving information about genetically modified food on the Web, Information Research, 10 (2) paper 213. Available: http://InformationR.net/ir/10-2/paper213.html

MCMURDO, G. (1998), Evaluating Web information and design, Journal of Information Science, 24 (3) : 192.204.

MICHAVILA, F. (2001), La salida del Laberinto, Editorial Complutense, Madrid.

MICHAVILA, F., GARCÍA, J. \& RODRÍGUEZ, R. (Eds.)(2001), Innovaciones en la organización y gestión de las universidades, Dirección General de Universidades de la Consejería de Educación de la Comunidad de Madrid y Cátedra UNESCO de Gestión y Política Universitaria de la Universidad Politécnica de Madrid, Madrid.

MICHAVILA, F. \& MARTÍNEZ, J. (Eds.)(2002), El carácter transversal en la educación universitaria, Dirección General de Universidades de la Consejería de Educación de la Comunidad de Madrid y Cátedra UNESCO de Gestión y Política Universitaria de la Universidad Politécnica de Madrid, Madrid.

MICHEL, J. (2004), Enjeux, concepts-clés et pratiques de la gestion des connaissances : le rôle des documentalistes dans la construction et la consolidation des savoirs collectifs, in Les Rencontres 2004 des Professionnels de l'IST, Journées de formation des documentalistes de la Recherche Nancy - Palais des Congrès - 15, 16 et 17 juin 2004. Available http://michel.jean.free.fr/publi/JM347.html

MILLER, H. (1996), The multiple dimensions of information quality, Information Systems Management, 13 (2) : 79.83.

MIRANDA GONZÁLEZ, F.J. \& BAÑEGIL PALACIOS, T.M. (2004), Quantitative evaluation of commercial web sites: an empirical study of Spanish firms, International Journal of Information Management, 24 : 313.328.

MORA, J. G. (1991), La evaluación institucional: una perspectiva general, in De Miguel et al (Eds.), La evaluación de las instituciones universitarias, Consejo de Universidades, Madrid, pp. 73-92.

OLSINA, L., GODOY, D., LAFUENTE, G. \& ROSSI, G. (1999), Quality characteristics and attributes for academic Web sites, Web Engineering Workshop at WWW8. Toronto, Canada.

PINTO, M., SAlES, D., DOUCET, A.V., FERNÁNDEZ-RAMOS, A. \& GUERRERO, D. (2007), Metric Analysis of the Information visibility and diffusion about the European Higher Education Area on Spanish University Websites, Scientometrics, 72 (2) : 345.370.

PITSCHMANN, L. A. (2001), Building sustainable collections of free third-party web resources. DLI; Council on Library and Information Resources. Available: http://www.clir.org/PUBS/reports/pub98/contents.html

REICHERT, S. \& TAUCH, C. (2005), Trends in European Higher Education: European Universities Implementing Bologna, European University Association (EUA). Available: http://www.eua.be/eua/jsp/en/upload/TrendsIV_FINAL.1117012084971.pdf 
SCONUL (1999), Information Skills Task Force. Information skills in higher education: a SCONUL position paper. Society of College, National and University Libraries, London Available: http://www.sconul.ac.uk/activities/inf_lit/papers/Seven_pillars2.pdf

SEMINARIO INTERNACIONAL SOBRE EVALUACIÓN DE LA CALIDAD Y LA ACREDITACIÓN EN LA ENSEÑANZA SUPERIOR UNIÓN EUROPEA AMÉRICA LATINA Y EL CARIBE (UEALC) (2003), Madrid, 3-5 de febrero de 2003. Espacio Común de Enseñanza Superior de la Unión Europea, América Latina y el Caribe. Available: http://www.aneca.es

SMITH, A. G. (1997), Testing the Surf: Criteria for Evaluating Internet Information Resources, The Public-Access Computer Systems Review, 8 (3). Available: http://info.lib.uh.edu/pr/v8/n3/smit8n3.html

UNIVERSIA. Available www.universia.com

UNESCO (2005), Towards knowledge societies. Available http://unesdoc.unesco.org/images/0014/001418/141843s.pdf

UNESCO (1998), World Declaration on Higher Education for the $21^{\text {st }}$ Century: vision and action. Available http://www.unesco.org/education/educprog/wche/declaration eng.htm

WALTHER, J.B., GAY, G. \& HANCOCK, J.T. (2005), How do communication and technology researchers study the Internet?, Journal of Communication, 55 (3) : 632.657.

W3C (1999), Checklist of Checkpoints for Web Content Accessibility Guidelines 1.0. Available: http://www.w3.org/TR/WCAG10/full-checklist.html

ZHANG, J. \& DIMITROFF, A. (2005), The impact of metadata implementation on webpage visibility in search engine results (Part II), Information Processing and Management, 41 : 691.715. 
FIGURES

Figure 1: Box plot of the 7 criteria

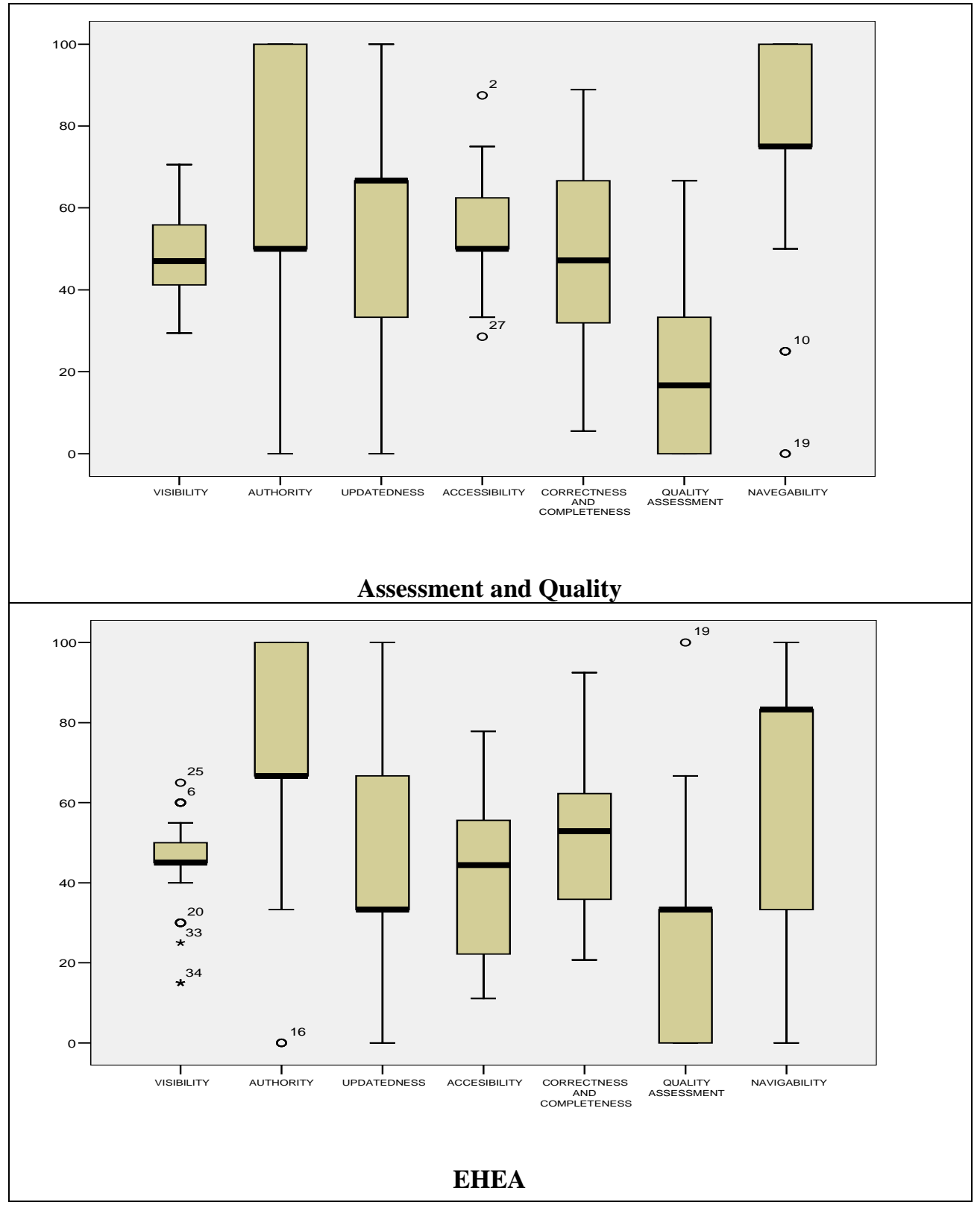




\section{Figure 2: Visibility - Correctness and Completeness Coordinates}

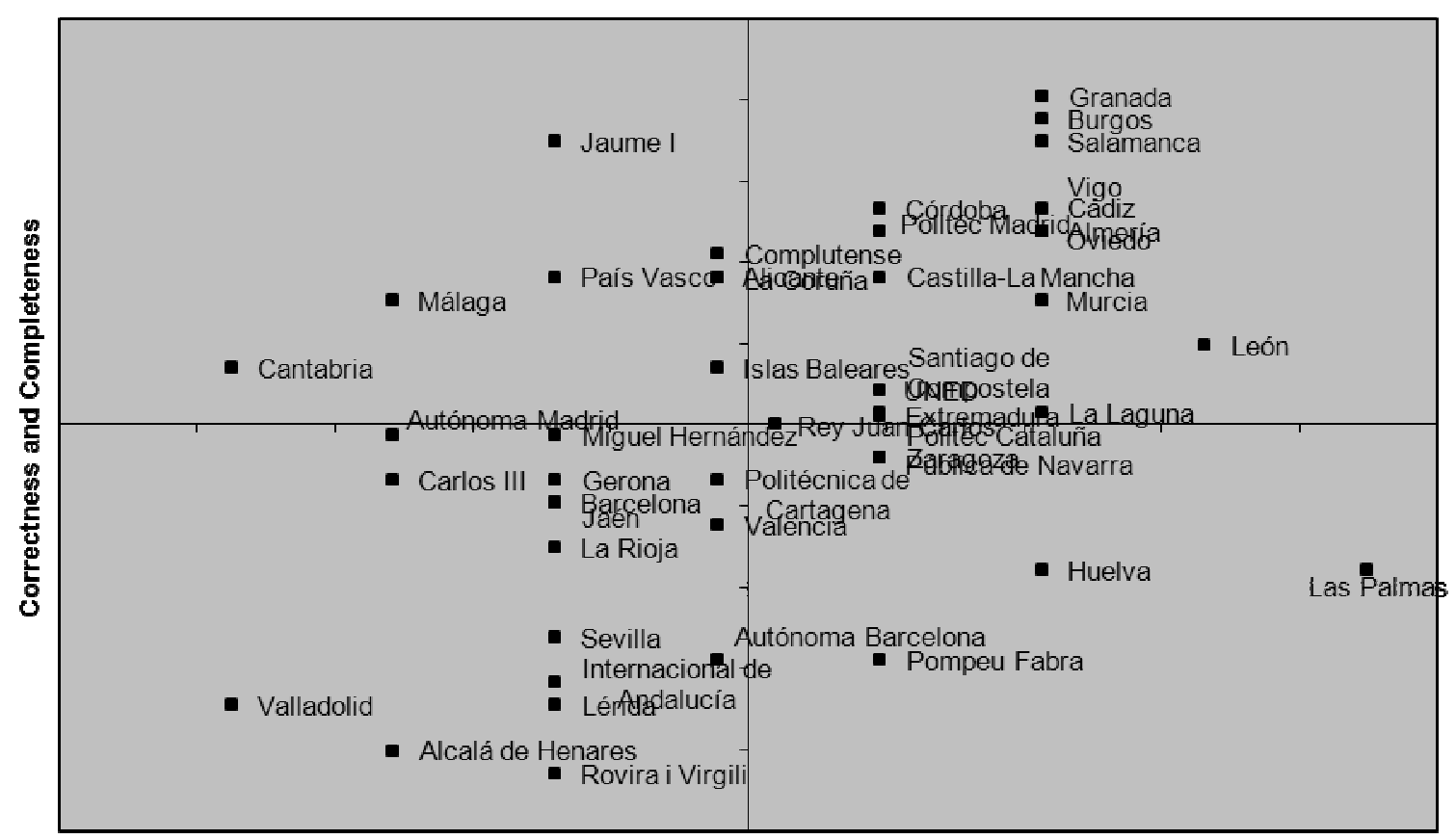

Visibility

\section{TABLES}

\begin{tabular}{|c|c|c|c|}
\hline 1. & & Visibility & 17 \\
\hline \multirow{3}{*}{1.1} & \multirow{3}{*}{ Entry from the home page } & It exists & 1 \\
\hline & & It is easy to find & 1 \\
\hline & & Term used is clearly identifiable & 1 \\
\hline \multirow[t]{3}{*}{1.3} & \multirow[t]{3}{*}{ Overall sitemap of the University website } & It exists & 1 \\
\hline & & The map has links to the contents & 1 \\
\hline & & In the EHEA & 1 \\
\hline \multirow{2}{*}{1.4} & \multirow{2}{*}{ Table of contents of the University } & There is a comment for the link (section) that identifies its contents & 1 \\
\hline & & The information is arranged in sections that open up hierarchically & 1 \\
\hline \multirow[t]{3}{*}{1.5} & \multirow[t]{3}{*}{ Table of contents of the EHEA } & It exists & 1 \\
\hline & & There is a comment for the link (section) that identifies its contents & 1 \\
\hline & & The information is arranged in sections that open up hierarchically & 1 \\
\hline 1.6 & Internal search engine & There is a search engine for the university & 1 \\
\hline 2. & \multicolumn{2}{|r|}{ Authority } & 2 \\
\hline 2.1 & $\begin{array}{l}\text { The University logo and name appear on the } \\
\text { page dedicated to the EHEA }\end{array}$ & The University logo and name appear on each page & 1 \\
\hline 2.2 & Webmaster is stated on the home page & There is a webmaster & 1 \\
\hline 3. & & Updatedness & 3 \\
\hline 3.1 & Updating of information & The date of the last update appears & 1 \\
\hline \multirow[t]{2}{*}{3.2} & \multirow[t]{2}{*}{ Dead links } & There are no links beyond one month old & 1 \\
\hline & & $\begin{array}{l}\text { It is stated whether the deadlines involved in announcements have } \\
\text { finished or not }\end{array}$ & 1 \\
\hline 4. & & Accessibility & 6 \\
\hline 4.1 & $\begin{array}{l}\text { Design is compatible with different browsers } \\
\text { /screen resolutions }\end{array}$ & $\begin{array}{l}\text { There are no distortions when viewing the home pages (Mozilla, } \\
\text { Netscape..) }\end{array}$ & 1 \\
\hline
\end{tabular}




\begin{tabular}{|c|c|c|c|}
\hline 4.4 & Help on the web structure and navigation & It exists & 1 \\
\hline 4.5 & Possibility of choosing English language & There is a version in English & 1 \\
\hline 5. & \multicolumn{2}{|c|}{ Correctness and completeness } & 35 \\
\hline \multirow[t]{2}{*}{5.1} & \multirow[t]{2}{*}{$\begin{array}{l}\text { Analysis of the first } 10 \text { hits in Google and } \\
\text { Yahoo }\end{array}$} & $\begin{array}{l}\text { Where they rank on the list of hits following the search query } \\
\text { UNIVERSIDAD X "ESPACIO EUROPEO DE EDUCACIÓN } \\
\text { SUPERIOR" }\end{array}$ & 1 \\
\hline & & $\begin{array}{l}\text { Where they rank on the list of hits following the search query } \\
\text { UNIVERSITY X "EUROPEAN HIGHER EDUCATION AREA" }\end{array}$ & 1 \\
\hline \multirow{5}{*}{5.2} & \multirow{5}{*}{ General Information } & Email address given & 1 \\
\hline & & \begin{tabular}{|l|} 
Service charter \\
\end{tabular} & 1 \\
\hline & & \begin{tabular}{|l|} 
Explanation of quality assesment \\
\end{tabular} & 1 \\
\hline & & $\begin{array}{l}\text { Participation in the institutional framework (MEC, ANECA, Quality } \\
\text { standards agencies) }\end{array}$ & 1 \\
\hline & & Specific links & 1 \\
\hline \multirow{3}{*}{5.3} & \multirow{3}{*}{ Rules } & Links to the documents & 1 \\
\hline & & Links to related institutions (Ministries, European Union, etc.) & 1 \\
\hline & & Links to specific software required to view the documents (Adobe) & 1 \\
\hline \multirow[t]{2}{*}{5.4} & \multirow[t]{2}{*}{ Congresses, seminars, conferences, workshops } & Calendar of events & 1 \\
\hline & & Updated information & 1 \\
\hline \multirow[t]{7}{*}{5.5} & \multirow[t]{7}{*}{ Programmes } & Training for quality & 1 \\
\hline & & Internal evaluation of qualifications & 1 \\
\hline & & Final evaluation of qualifications & 1 \\
\hline & & nternal evaluation of departments & 1 \\
\hline & & Final evaluation of departments & 1 \\
\hline & & Internal evaluation of services & 1 \\
\hline & & Directory of staff in positions of responsibility & 1 \\
\hline \multirow[t]{4}{*}{5.6} & \multirow[t]{4}{*}{ Announcements } & Specific to the agencies & 1 \\
\hline & & Outcomes / follow-up & 1 \\
\hline & & National & 1 \\
\hline & & Outcomes / follow-up & 1 \\
\hline 5.7 & Important news is highlighted & It exists & 1 \\
\hline 6 & \multicolumn{2}{|r|}{ Quality Assessment } & 3 \\
\hline 6.1 & Quality policy statement on the website & It exists & 1 \\
\hline 6.2 & Suggestion box & It exists & 1 \\
\hline 6.3 & $\begin{array}{l}\text { Survey on user satisfaction regarding the } \\
\text { website }\end{array}$ & It exists & 1 \\
\hline 7. & & Navigability & 4 \\
\hline \multirow[t]{2}{*}{7.1} & \multirow[t]{2}{*}{ Contents menu always visible } & On all the pages & 1 \\
\hline & & In the same place & 1 \\
\hline 7.2 & Consistent terminology & The same term is used in every section & 1 \\
\hline 7.3 & Navigation buttons & It is possible to go up to a more generic level & 1 \\
\hline
\end{tabular}

Table 1: Template

\begin{tabular}{|l|l|l|}
\hline Percentage & Score & Rating \\
\hline From $0 \%$ to $20 \%$ & 1 & Not acceptable (NA) \\
\hline From $21 \%$ to $40 \%$ & 2 & Poor (P) \\
\hline From $41 \%$ to $60 \%$ & 3 & Acceptable (A) \\
\hline From $61 \%$ to $80 \%$ & 4 & Good (G) \\
\hline From $81 \%$ to $100 \%$ & 5 & Very Good (VG) \\
\hline
\end{tabular}

Table 2: Percentages and numerical values 


\begin{tabular}{|l|c|c|l|}
\hline RATING & FREQUENCY & PERCENTAGE & UNIVERSITIES \\
\hline G & 2 & $4.26 \%$ & ulpgc, unileon \\
\hline A & 39 & $82.98 \%$ & $\begin{array}{l}\text { upc, ub, uniovi, ehu, us, uab, ual, uca, uned, ubu, } \\
\text { uclm, ucm, uric, udl, ua, uv, unex, uji, ull, umh, urv, } \\
\text { upct, uvigo, ull, um, unizar, udc, upm, usal, ugr, usc, } \\
\text { ujaen, uib, unia }\end{array}$ \\
\hline P & 6 & $12.77 \%$ & uah, uam, uc3m, uma, unican, uva \\
\hline
\end{tabular}

Table 3: Results obtained on visibility

\begin{tabular}{|l|c|c|l|}
\hline RATING & FREQUENCY & PERCENTAGE & UNIVERSITIES \\
\hline VG & 14 & $29.79 \%$ & $\begin{array}{l}\text { Uam, uab, ua, ual, ubu, uca, udg, ugr, uib, unirioja, } \\
\text { upf, usal, uv, unileon }\end{array}$ \\
\hline A & 32 & $68.09 \%$ & $\begin{array}{l}\text { Uah, uc3m, uma, unican, uva, ehu, ub, uclm, ucm, } \\
\text { uco, udc, udl, uhu, ujaen, uji, ull, um, umh, unavarra, } \\
\text { uned, unex, unia, uniovi, unizar, upct, upm, utjc, urv, } \\
\text { usc, uvigo, ulpgc }\end{array}$ \\
\hline NA & 1 & $2.13 \%$ & use \\
\hline
\end{tabular}

Table 4: Results obtained on authority

\begin{tabular}{|l|c|c|l|}
\hline RATING & FREQUENCY & PERCENTAGE & UNIVERSITIES \\
\hline VG & 1 & $2.13 \%$ & Ua \\
\hline G & 11 & $23.40 \%$ & $\begin{array}{l}\text { Ehu, udc, udl, uib, uji, unex, upct, upf, urv, uvigo, } \\
\text { ulpgc }\end{array}$ \\
\hline A & 12 & $25.53 \%$ & $\begin{array}{l}\text { Uah, uab, uca, uco, uhu, ujaen, umh, unizar, urjc, } \\
\text { usc, use, uv }\end{array}$ \\
\hline P & 23 & $48.94 \%$ & $\begin{array}{l}\text { Uam, uc3m, uma, unican, uva, ual, ub, ubu, uclm, } \\
\text { ucm, udg, ugr, ull, um, unavarra, UNED, unia, } \\
\text { uniovi, unirioja, upc, upm, usal, unileon }\end{array}$ \\
\hline
\end{tabular}

Table 5: Results obtained on updatedness

\begin{tabular}{|l|c|c|l|}
\hline RATING & FREQUENCY & PERCENTAGE & UNIVERSITIES \\
\hline VG & 1 & $2.13 \%$ & ua \\
\hline G & 11 & $23.40 \%$ & $\begin{array}{l}\text { ehu, udc, udl, uib, uji, ulpgc, unex, upc, upf, urv, } \\
\text { uvigo }\end{array}$ \\
\hline A & 12 & $25.53 \%$ & $\begin{array}{l}\text { uab, uah, uca, uco, uhu, ujaen, umh, unizar, urjc, } \\
\text { usc, use, uv }\end{array}$ \\
\hline P & 23 & $48.94 \%$ & $\begin{array}{l}\text { ual, uam, ub, ubu, uc3m, uclm, ucm, udg, ugr, ull, } \\
\text { um, uma, unavarra, uned, unia, unican, unileon, } \\
\text { uniovi, unirioja, upct, upm, usal, uva }\end{array}$ \\
\hline
\end{tabular}

Table 6: Results obtained on accessibility 


\begin{tabular}{|l|c|c|l|}
\hline RATING & FREQUENCY & PERCENTAGE & UNIVERSITIES \\
\hline VG & 4 & $8.51 \%$ & ubu, ugr, uji, usal \\
\hline G & 13 & $27.66 \%$ & $\begin{array}{l}\text { ehu, ua, ual, uca, uclm, ucm, uco, udc, um, uma, } \\
\text { uniovi, upm, uvigo }\end{array}$ \\
\hline A & 12 & $25.53 \%$ & $\begin{array}{l}\text { uam, uib, ull, umh, unavarra, uned, unican, unileon, } \\
\text { unizar, upc, urj, usc }\end{array}$ \\
\hline P & 10 & $21.28 \%$ & $\begin{array}{l}\text { ub, uc3m, udg, uhu, ujaen, ulpgc, unex, unirioja, } \\
\text { upct, uv }\end{array}$ \\
\hline NA & 8 & $17.02 \%$ & uab, uah, udl, unia, upf, urv, use, uva \\
\hline
\end{tabular}

Table 7: Results obtained on correctness and completeness

\begin{tabular}{|c|c|c|c|c|c|c|c|c|}
\hline Universities & Total & 5.1 & 5.2 & 5.3 & 5.4 & 5.5 & 5.6 & 5.7 \\
\hline $\begin{array}{l}\text { Maximum } \\
\text { possible score }\end{array}$ & 36 & 2 & 7 & 5 & 2 & 15 & 4 & 1 \\
\hline ugr & 31.00 & 1 & 6 & 3 & 2 & 14 & 4 & 1 \\
\hline $\mathrm{ubu}$ & 30.00 & 1 & 6 & 4 & 2 & 12 & 4 & 1 \\
\hline uji & 29.00 & 1 & 7 & 2 & 2 & 12 & 4 & 1 \\
\hline usal & 29.00 & 1 & 7 & 3 & 2 & 11 & 4 & 1 \\
\hline uco & 27.00 & 2 & 5 & 2 & 1 & 12 & 4 & 1 \\
\hline uvigo & 26.00 & 1 & 6 & 3 & 1 & 10 & 4 & 1 \\
\hline ual & 25.00 & 1 & 6 & 3 & 2 & 10 & 2 & 1 \\
\hline uca & 25.00 & 1 & 6 & 2 & 0 & 12 & 4 & 0 \\
\hline uniovi & 25.00 & 1 & 5 & 4 & 0 & 10 & 4 & 1 \\
\hline ehu & 24.00 & 2 & 4 & 2 & 1 & 10 & 4 & 1 \\
\hline ua & 24.00 & 2 & 6 & 3 & 2 & 6 & 4 & 1 \\
\hline upm & 24.00 & 0 & 6 & 2 & 0 & 11 & 4 & 1 \\
\hline uclm & 23.00 & 1 & 6 & 3 & 2 & 8 & 2 & 1 \\
\hline $\mathrm{ucm}$ & 23.00 & 0 & 5 & 2 & 1 & 10 & 4 & 1 \\
\hline udc & 23.00 & 1 & 6 & 1 & 1 & 9 & 4 & 1 \\
\hline $\mathrm{um}$ & 22.00 & 1 & 4 & 2 & 0 & 10 & 4 & 1 \\
\hline uma & 22.00 & 1 & 5 & 2 & 0 & 10 & 4 & 0 \\
\hline unileon & 20.00 & 1 & 5 & 3 & 0 & 9 & 2 & 0 \\
\hline uib & 19.00 & 1 & 3 & 1 & 1 & 8 & 4 & 1 \\
\hline unican & 18.00 & 0 & 6 & 2 & 0 & 6 & 4 & 0 \\
\hline uned & 17.00 & 1 & 4 & 3 & 0 & 4 & 4 & 1 \\
\hline usc & 17.00 & 0 & 6 & 2 & 2 & 5 & 2 & 0 \\
\hline uam & 16.00 & 1 & 5 & 1 & 2 & 4 & 2 & 1 \\
\hline ull & 16.00 & 0 & 4 & 2 & 1 & 8 & 0 & 1 \\
\hline unavarra & 16.00 & 2 & 5 & 4 & 0 & 1 & 4 & 0 \\
\hline umh & 15.00 & 0 & 7 & 4 & 0 & 1 & 2 & 1 \\
\hline unizar & 15.00 & 1 & 5 & 1 & 0 & 6 & 2 & 0 \\
\hline upct & 15.00 & 1 & 5 & 2 & 0 & 4 & 2 & 1 \\
\hline urjc & 15.00 & 1 & 3 & 1 & 0 & 6 & 4 & 0 \\
\hline $\mathrm{ub}$ & 14.00 & 2 & 5 & 1 & 0 & 4 & 2 & 0 \\
\hline unex & 14.00 & 1 & 6 & 2 & 0 & 3 & 2 & 0 \\
\hline upct & 14.00 & 1 & 4 & 2 & 0 & 7 & 0 & 0 \\
\hline $\mathrm{uc} 3 \mathrm{~m}$ & 13.00 & 0 & 3 & 1 & 0 & 6 & 3 & 0 \\
\hline ujaen & 13.00 & 1 & 4 & 3 & 1 & 2 & 2 & 0 \\
\hline $\mathrm{uv}$ & 13.00 & 2 & 4 & 4 & 1 & 1 & 0 & 1 \\
\hline unirioja & 11.00 & 1 & 6 & 3 & 0 & 1 & 0 & 0 \\
\hline udg & 10.00 & 1 & 4 & 1 & 1 & 2 & 0 & 1 \\
\hline uhu & 10.00 & 1 & 2 & 0 & 0 & 7 & 0 & 0 \\
\hline $\mathrm{u} \log \mathrm{c}$ & 9.00 & 0 & 3 & 1 & 0 & 5 & 0 & 0 \\
\hline aub & $\begin{array}{l}6.00 \\
\end{array}$ & 1 & 3 & 1 & 0 & 1 & 0 & 0 \\
\hline upf & 6.00 & 1 & 2 & 0 & 0 & 2 & 1 & 0 \\
\hline use & 6.00 & 0 & 2 & 0 & 0 & 0 & 4 & 0 \\
\hline unia & 5.00 & 1 & 1 & 0 & 0 & 3 & 0 & 0 \\
\hline udl & 4.00 & 1 & 2 & 0 & 0 & 0 & 0 & 1 \\
\hline uva & 4.00 & 1 & 2 & 1 & 0 & 0 & 0 & 0 \\
\hline uah & 2.00 & 1 & 1 & 0 & 0 & 0 & 0 & 0 \\
\hline
\end{tabular}




\begin{tabular}{|l|l|l|l|l|l|l|l|l|} 
urv & $\mathbf{2 . 0 0}$ & 2 & 0 & 0 & 0 & 0 & 0 & 0 \\
\hline
\end{tabular}

Table 8: Results obtained on each sub-criteria

\begin{tabular}{|l|c|c|l|}
\hline RATING & FREQUENCY & PERCENTAGE & UNIVERSITIES \\
\hline G & 4 & $8.51 \%$ & ua, uco, ugr, umh \\
\hline P & 20 & $42.55 \%$ & $\begin{array}{l}\text { uah, ehu, ual, ubu, uclm, ucm, udl, uhu, uib, ujaen, } \\
\text { uji, um, uned, uniovi, unirioja, unizar, upct, usal, } \\
\text { ulpgc, unileon }\end{array}$ \\
\hline NA & 23 & $48.94 \%$ & $\begin{array}{l}\text { uam, uc3m, uma, unican, uva, uab, ub, uca, udc, udg, } \\
\text { ull, unavarra, unex, unia, upc, upf, upm, urjc, urv, } \\
\text { usc, use, uv, uvigo }\end{array}$ \\
\hline
\end{tabular}

Table 9: Results obtained on quality assessment

\begin{tabular}{|l|c|c|l|}
\hline RATING & FREQUENCY & PERCENTAGE & UNIVERSITIES \\
\hline VG & 14 & $29.79 \%$ & $\begin{array}{l}\text { uah, uma, uab, ua, ual, ubu, uca, uclm, uco, uhu, } \\
\text { umh, uned, uvigo, unileon }\end{array}$ \\
\hline G & 24 & $51.06 \%$ & $\begin{array}{l}\text { uam, unican, uva, ehu, ub, udc, udg, udl, uib, ujaen, } \\
\text { uji, ull, unavarra, unia, uniovi, unirioja, unizar, upc, } \\
\text { upct, upf, upm, usal, usc, uv }\end{array}$ \\
\hline A & 5 & $10.64 \%$ & ugr, um, unex, urjc, use \\
\hline P & 3 & $6.38 \%$ & uc3m, ucm, ulpgc \\
\hline NA & 1 & $2.13 \%$ & urv \\
\hline
\end{tabular}

Table 10: Results obtained on navigability

\begin{tabular}{|c|c|c|c|c|c|c|c|c|}
\hline & Total & VISIBILITY & AUTHORITY & UPDATEDNESS & ACCESSIBILITY & $\begin{array}{c}\text { CORRECTNESS } \\
\text { AND } \\
\text { COMPLETENESS }\end{array}$ & $\begin{array}{c}\text { QUALITY } \\
\text { ASSESSMENT }\end{array}$ & NAVIGABILITY \\
\hline 1 & ugr - 79.10 & ulpgc - 70.59 & ua - 100 & ua - 100 & ua -87.5 & ugr - 88.57 & ua - 66.67 & ua - 100 \\
\hline 2 & ubu - 77.61 & unileon - 64.70 & uab - 100 & $\mathrm{ub}-100$ & ehu -75 & ubu - 85.71 & uco - 66.67 & uab - 100 \\
\hline 3 & uco -74.63 & ual - 58.82 & ual - 100 & uclm - 100 & urv -75 & uji - 82.86 & ugr - 66.67 & uah - 100 \\
\hline 4 & ua - 72.46 & ubu -58.82 & uam - 100 & uco - 100 & uvigo -75 & usal - 82.86 & umh - 66.67 & ual - 100 \\
\hline 5 & usal - 72.06 & uca - 58.82 & ubu - 100 & ugr - 100 & ulpgc - 71.43 & uco - 77.14 & ehu -33.33 & ubu -100 \\
\hline 6 & uji - 69.56 & ugr - 58.82 & uca - 100 & uib - 100 & ujaen - 66.67 & uvigo -74.28 & uah -33.33 & uca - 100 \\
\hline 7 & uvigo - 69.56 & uhu -58.82 & udg - 100 & uned - 100 & unizar - 66.67 & ual - 71.43 & ual - 33.33 & uclm - 100 \\
\hline 8 & uca -69.18 & ull - 58.82 & ugr - 100 & uah - 66.67 & use - 66.67 & uca -71.43 & ubu -33.33 & uco - 100 \\
\hline 9 & ual - 68.66 & um - 58.82 & uib - 100 & ual - 66.67 & udc -62.5 & uniovi - 71.43 & uclm - 33.33 & uhu - 100 \\
\hline 10 & uclm - 65.67 & uniovi - 58.82 & unileon - 100 & uam - 66.67 & udl - 62.5 & ehu - 68.57 & ucm - 33.33 & uma - 100 \\
\hline 11 & uniovi - 65.67 & usal - 58.82 & unirioja - 100 & ubu - 66.67 & uib - 62.5 & ua - 68.57 & udl - 33.33 & umh - 100 \\
\hline 12 & ehu - 62.32 & uvigo - 58.82 & upf - 100 & uca - 66.67 & uji -62.5 & upm - 68.57 & uhu - 33.33 & uned - 100 \\
\hline 13 & unileon - 61.76 & uclm - 52.94 & usal - 100 & udc -66.67 & unex -62.5 & uclm - 65.71 & uib - 33.33 & unileon - 100 \\
\hline 14 & upm - 61.19 & uco - 52.94 & $u v-100$ & udg - 66.67 & upc -62.5 & ucm - 65.71 & ujaen - 33.33 & uvigo - 100 \\
\hline 15 & udc - 60.87 & unavarra -52.94 & ehu - 50 & udl - 66.67 & upf - 62.5 & udc - 65.71 & uji - 33.33 & ehu - 75 \\
\hline 16 & uib - 59.42 & uned -52.94 & uah - 50 & uhu - 66.67 & uhu - 57.14 & um - 62.86 & ulpgc -33.33 & uam - 75 \\
\hline 17 & um - 58.21 & unex - 52.94 & $\mathrm{ub}-50$ & uji - 66.67 & umh - 57.14 & uma - 62.86 & um - 33.33 & $\mathrm{ub}-75$ \\
\hline 18 & uma - 56.72 & unizar - 52.94 & uc $3 m-50$ & ull - 66.67 & urjc - 57.14 & unileon - 57.14 & uned - 33.33 & udc -75 \\
\hline 19 & ucm - 55.22 & upc - 52.94 & uclm - 50 & uma - 66.67 & uab - 50 & uib - 54.28 & unileon - 33.33 & udg - 75 \\
\hline 20 & uned - 55.22 & upf - 52.94 & ucm - 50 & umh - 66.67 & uah - 50 & unican - 51.43 & uniovi - 33.33 & udl - 75 \\
\hline 21 & ull - 52.24 & upm - 52.94 & uco - 50 & unavarra - 66.67 & uca - 50 & uned - 48.57 & unirioja - 33.33 & uib - 75 \\
\hline 22 & upc - 52.17 & usc - 52.94 & udc -50 & unex - 66.67 & uco - 50 & usc - 48.57 & unizar - 33.33 & ujaen - 75 \\
\hline 23 & umh - 51.47 & ua - 47.06 & udl - 50 & unileon - 66.67 & ull - 50 & uam - 45.71 & upc -33.33 & uji - 75 \\
\hline 24 & unavarra -50.75 & uab - 47.06 & uhu - 50 & unirioja - 66.67 & um - 50 & ull - 45.71 & usal - 33.33 & ull - 75 \\
\hline 25 & usc - 49.27 & ucm - 47.06 & ujaen - 50 & upc - 66.67 & uma - 50 & unavarra - 45.71 & uab - 0 & unavarra - 75 \\
\hline 26 & unizar - 49.25 & udc - 47.06 & uji - 50 & upm - 66.67 & unavarra - 50 & umh - 42.86 & uam - 0 & unia - 75 \\
\hline 27 & unex - 48.53 & uib - 47.06 & ull - 50 & uv - 66.67 & unia - 50 & unizar - 42.86 & $\mathrm{ub}-0$ & unican - 75 \\
\hline 28 & uam - 47.76 & upct - 47.06 & ulpgc -50 & ehu -33.33 & uniovi - 50 & upc - 42.86 & uc $3 m-0$ & uniovi - 75 \\
\hline 29 & uhu - 47.06 & urjc - 47.06 & um - 50 & uab - 33.33 & upct - 50 & urjc - 42.86 & uca - 0 & unirioja - 75 \\
\hline 30 & uv - 46.38 & uv - 47.06 & uma - 50 & uc $3 m-33.33$ & usc -50 & $\mathrm{ub}-40$ & udc - 0 & unizar - 75 \\
\hline 31 & unican - 46.27 & ehu - 41.18 & umh - 50 & ujaen - 33.33 & uv - 50 & unex - 40 & udg - 0 & upc - 75 \\
\hline 32 & urjc -45.59 & $\mathrm{ub}-41.18$ & unavarra - 50 & ulpgc -33.33 & usal - 42.86 & upct - 40 & ull - 0 & upct - 75 \\
\hline 33 & $\mathrm{ub}-44.93$ & udg -41.18 & uned - 50 & unia - 33.33 & uam - 37.5 & uc $3 m-37.14$ & uma - 0 & upf - 75 \\
\hline 34 & ujaen - 44.78 & udl - 41.18 & unex - 50 & unican - 33.33 & $\mathrm{ub}-37.5$ & ujaen - 37.14 & unavarra - 0 & upm - 75 \\
\hline
\end{tabular}




\begin{tabular}{|c|c|c|c|c|c|c|c|c|}
\hline 35 & upct -44.78 & ujaen - 41.18 & unia -50 & uniovi - 33.33 & ubu -37.5 & uv - 37.14 & unex - 0 & usal - 75 \\
\hline 36 & ulpgc -44.12 & uji - 41.18 & unican - 50 & upct - 33.33 & uc $3 m-37.5$ & unirioja - 31.43 & unia - 0 & usc - 75 \\
\hline 37 & unirioja - 43.28 & umh - 41.18 & uniovi - 50 & upf - 33.33 & uclm - 37.5 & udg - 28.57 & unican - 0 & uv - 75 \\
\hline 38 & udg - 39.13 & unia - 41.18 & unizar - 50 & urjc -33.33 & $\mathrm{ucm}-37.5$ & uhu - 28.57 & upct - 0 & uva -75 \\
\hline 39 & upf - 37.68 & unirioja - 41.18 & upc - 50 & urv - 33.33 & udg - 37.5 & ulpgc - 25.71 & upf - 0 & ugr - 50 \\
\hline 40 & $\mathrm{uc} 3 \mathrm{~m}-37.31$ & urv -41.18 & upct - 50 & usal - 33.33 & ugr - 37.5 & uab - 17.14 & upm - 0 & um - 50 \\
\hline 41 & uab - 36.23 & use -41.18 & upm - 50 & use - 33.33 & unican - 37.5 & upf - 17.14 & urjc - 0 & unex - 50 \\
\hline 42 & udl - 33.33 & uah - 35.29 & urjc -50 & uvigo - 33.33 & unirioja - 37.5 & use -17.14 & urv - 0 & urjc - 50 \\
\hline 43 & uah - 32.35 & uam - 35.29 & urv - 50 & $\mathrm{ucm}-0$ & uned - 33.33 & unia - 14.28 & usc - 0 & use - 50 \\
\hline 44 & unia - 29.85 & uc $3 m-35.29$ & usc - 50 & um - 0 & upm - 33.33 & uah - 5.71 & use - 0 & uc $3 m-25$ \\
\hline 45 & use - 29.85 & uma - 35.29 & uva - 50 & unizar - 0 & uva -33.33 & udl - 11.43 & uv - 0 & $\mathrm{ucm}-25$ \\
\hline 46 & urv - 24.64 & unican - 29.41 & uvigo - 50 & usc - 0 & unileon - 28.57 & uva -11.43 & uva - 0 & ulpgc -25 \\
\hline 47 & uva -22.39 & uva - 29.41 & use - 0 & uva - 0 & ual - 25 & urv - 5.71 & uvigo - 0 & urv - 0 \\
\hline
\end{tabular}

Table 11: Overall results of the universities

\begin{tabular}{|l|c|c|c|c|}
\hline & \multicolumn{2}{|c|}{ Assessment and quality (N=47) } & \multicolumn{2}{c|}{ EHEA (N=45) } \\
\hline Criteria & Mean & Std Derivation & Mean & Std Derivation \\
\hline Visibility of Information & 4.82 & 9.68 & 4.54 & 11.42 \\
\hline Authority & 6.35 & 24.71 & 6.96 & 25.48 \\
\hline Updatedness & 5.34 & 28.96 & 4.29 & 25.25 \\
\hline Accessibility & $\mathbf{5 . 4 7}$ & $\mathbf{1 2 . 7 3}$ & $\mathbf{4 . 0 4}$ & $\mathbf{1 6 . 0 9}$ \\
\hline Correctness and Completeness & 4.85 & 22.79 & 5.21 & 16.96 \\
\hline Quality Assessment & 1.94 & 21.56 & 1.93 & 21.89 \\
\hline Navigability & 7.29 & 25.18 & 6.44 & 34.55 \\
\hline
\end{tabular}

Tabla 12: Assessment and quality vs. EHEA

\begin{tabular}{|ll}
\hline Acronym & University (alphabetical order) \\
\hline udc & A Coruña \\
uah & Alcalá de Henares \\
\hline ua & Alicante \\
ual & Almería \\
\hline uab & Aut. Barcelona \\
uam & Aut. Madrid \\
\hline ub & Barcelona \\
ubu & Burgos \\
\hline uca & Cádiz \\
unican & Cantabria \\
\hline uc3m & Carlos III \\
uclm & Castilla-La Mancha \\
\hline ucm & Complutense \\
\hline uco & Córdoba \\
\hline unex & Extremadura \\
\hline udg & Girona \\
\hline ugr & Granada \\
\hline uhu & Huelva \\
\hline uia & Internacional de Andalucía \\
\hline uib & Illes Balears \\
\hline ujaen & Jaén \\
\hline uji & Jaume I \\
\hline ull & La Laguna \\
\hline unirioja & La Rioja \\
\hline
\end{tabular}

Table 13: Acronyms of the universities

\begin{tabular}{|ll|}
\hline Acronym & University (alphabetical order) \\
ulpgc & Las Palmas \\
unileon & León \\
udl & Lleida \\
uma & Málaga \\
umh & Miguel Hernández \\
\hline um & Murcia \\
\hline uned & UNED \\
\hline uniovi & Oviedo \\
\hline ehu & País Vasco \\
\hline upct & Pol. Cartagena \\
\hline upc & Pol. Cataluña \\
\hline upm & Pol. Madrid \\
\hline upf & Pompeu Fabra \\
\hline unavarra & Pública de Navarra \\
\hline urjc & Rey Juan Carlos \\
\hline urv & Rovira i Virgili \\
\hline usal & Salamanca \\
\hline usc & Santiago Compostela \\
\hline us & Sevilla \\
\hline uv & Valencia \\
\hline uva & Valladolid \\
\hline uvigo & Vigo \\
\hline unizar & Zaragoza \\
\hline
\end{tabular}

